\title{
THE TEACCH APPROACH TO AUTISM SPECTRUM DISORDERS
}




\title{
THE TEACCH APPROACH TO AUTISM SPECTRUM DISORDERS
}

\author{
Gary B. Mesibov \\ University of North Carolina \\ Chapel Hill, NC

\section{Victoria Shea} \\ University of North Carolina \\ Chapel Hill, NC \\ and \\ Eric Schopler \\ University of North Carolina \\ Chapel Hill, NC \\ with \\ Lynn Adams Elif Merkler \\ Sloane Burgess Matt Mosconi \\ S. Michael Chapman Christine Tanner \\ Mary E. Van Bourgondien
}

Springer 
The TEACCH approach to autism spectrum disorders / Gary B. Mesibov,

Victoria Shea, Eric Schopler.

p. ; cm.

Includes bibliographical references and index.

ISBN 978-1-4757-0990-2

ISBN 978-0-306-48647-0 (eBook)

DOI 10.1007/978-0-306-48647-0

1. Autism. I. Mesibov, Gary B. II. Shea, Victoria. III. Schopler, Eric.

[DNLM: 1. Autistic Disorder-rehabilitation. 2. Education, Special-methods.

3. Professional-Family Relations. WM 203.5 T2528 2004]

RC553.A88T43 2004

$618.92^{\prime} 85882-\mathrm{dc} 21$

ISBN 978-1-4757-0990-2

Softcover reprint of the hardcover 1st edition 2004

Springer Science+Business Media, Inc.

233 Spring Street, New York, New York 10013

springeronline.com

1098765432

A C.I.P. record for this book is available from the Library of Congress.

\section{All rights reserved}

No part of this work may be reproduced, stored in a retrieval system, or transmitted in any form or by any means, electronic, mechanical, photocopying, microfilming, recording, or otherwise, without written permission from the Publisher, with the exception of any material supplied specifically for the purpose of being entered and executed on a comptuer system, for exclusive use by the purchaser of the work

Permissions for books published in Europe: permissions@wkap.rl Permissions for books published in the United States of America: permissions@wkap.com 


\section{Preface}

For over 30 years, Treatment and Education of Autistic and related Communication handicapped Children (TEACCH) has been an innovator in developing and implementing a state-wide system for assisting and supporting people with autism spectrum disorders and their families in North Carolina. The TEACCH program has both served the citizens of North Carolina and been a model for services throughout the country and all over the world. TEACCH has developed a conceptual model for understanding autism spectrum disorders (called the Culture of Autism) that has facilitated comprehension of autism spectrum disorders by parents and professionals. This understanding, in turn, has yielded a set of intervention strategies (called Structured Teaching) that provide an organizing foundation for classrooms, homes, and community-based services throughout the world.

The purpose of this book is to describe the TEACCH program and explain its many facets that reflect the conceptual model, based on the notion that autism is a neuropsychological disorder and that intervention strategies should be closely linked to empirical findings about neuropsychological functioning in autism.

The first chapter, which was written by Eric Schopler, the co-founder of TEACCH, traces the history of the TEACCH program. Chapter 2, written by Gary Mesibov, the current Director of TEACCH, delineates the core values that those working in the organization share and espouse. Chapters 3 and 4 introduce the TEACCH concept of the Culture of Autism and describe the Structured Teaching approach, and Chapter 5 explains the relationship of the TEACCH approach to other theoretical models. Chapters 6 and 7 cover the empirical literature and describe the strategies TEACCH has developed for teaching communication and social skills that people with ASD need to be successful in our society. Elif Merkler and Matt Mosconi made major contributions to the chapter on social skills.

Chapters 8 and 9 describe the research literature about parents of individuals with autism, and review TEACCH's multi-faceted work with parents, including ways that TEACCH professionals communicate with them about their youngster's autism and its implications. Chapters 10 and 11 discuss the 
application of TEACCH principles to the specialized populations of preschool children and adults with autism, respectively. Christie Tanner and Sloane Burgess took the lead in writing the preschool chapter, and the adult chapter was written by Mary Beth Van Bourgondien and Mike Chapman. Finally, Chapter 12, written by Lynn Adams, addresses the issue of training professionals to understand the TEACCH approach.

Although the authors who have taken the responsibility for organizing and writing the various sections are those listed on the book cover, this book is, in reality, the work of a much larger number of people over many years. There are too many of them to acknowledge individually but their hard work, support, and commitment are the heart of what the TEACCH program has become. Special thanks are also offered to our publishers, Kluwer Academic/Plenum Publishers, for their patience and support of this project and especially our Editor, Mariclaire Clouiter. Our wonderful secretarial staff including Joan Berry and Jill Cagle provided typing and all of the administrative support in their usual efficient and gracious fashion. Of course the major source of inspiration for this book is the people with ASD themselves and their courageous families, who teach us every day about autism and how people can face a difficult challenge with great courage, persistence, and class. They elevate all of us who are privileged to know and work with them. 


\section{Contents}

1. The Origins and History of the TEACCH Program ........... 1

2. Core Values of the TEACCH Program $\ldots \ldots \ldots \ldots \ldots \ldots \ldots \ldots, 13$

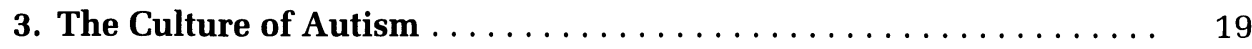

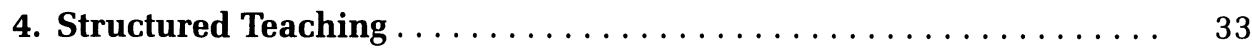

5. The Theoretical Context of Structured Teaching $\ldots \ldots \ldots \ldots \ldots \ldots \quad 51$

6. Communication ........................... 57

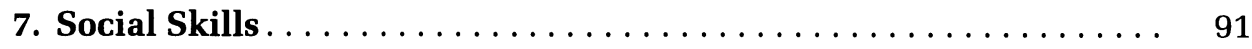

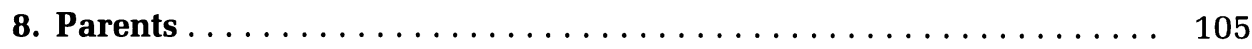

9. Providing Diagnostic Information to Parents . . . . . . . . . . . 129

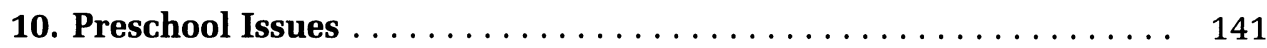

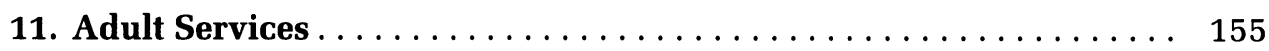

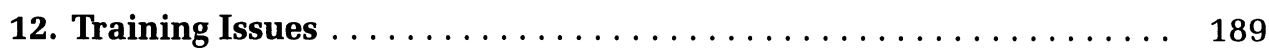

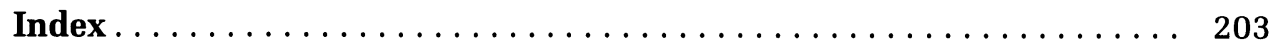




\section{THE TEACCH APPROACH TO AUTISM SPECTRUM DISORDERS}

